\title{
INFLUENCE OF DREDGED SEDIMENT ON THE SHRINKAGE BEHAVIOR OF SELF-COMPACTING CONCRETE
}

\author{
VPLIV IZKOPANIH SEDIMENTOV NA KRČENJE \\ SAMOZGOŠČEVALNEGA BETONA
}

\author{
Nasr-Eddine Bouhamou, Fouzia Mostefa, Abdelkader Mebrouki, Karim Bendani, \\ Nadia Belas \\ LCTPE Laboratory, Civil Engineering Department, Mostaganem University, Route de Belahcel BP 227, 27000 Mostaganem, Algeria
}

Prejem rokopisa - received: 2013-10-16; sprejem za objavo - accepted for publication: 2015-02-10

doi: $10.17222 /$ mit. 2013.252

\begin{abstract}
Every year, millions of cubic meters of dams and restraints are dredged as part of the management and prevention procedures all over the world. These dredged sediments are considered as natural waste leading to environmental, ecological and even economic problems associated with their processing and depositing. Nevertheless, in the context of a sustainable development policy, a way of their management is open aiming at assessing the sediments as a building material and, particularly, as a new binder that can be industrially exploited and that can improve the physical, chemical and mechanical characteristics of the concrete. This study is a part of the research made at the Civil Engineering Department at the University of Mostaganem (Algeria) on the impact of the mud dredged from the Fergoug Dam on the behavior of self-consolidating concrete (SCC) in the fresh and hardened states, such as the mechanical performance and its impact on different deformations (shrinkage). The work aims to assess this mud in the SCC and to show possible interactions between the constituents. The obtained results provide the details needed for producing the SCC based on calcined mud.

Keywords: sediment, calcined mud, self-consolidating concrete, fresh state, hard state, shrinkage
\end{abstract}

Vsako leto po vsem svetu kot varovalni ukrep izkopljejo milijone kubičnih metrov sedimentov iz jezov in zadrževalnikov. Ti izkopani sedimenti so obravnavani kot naravni odpadek, ki povzroča okoljske, ekološke in celo ekonomske težave pri njihovi predelavi ali odlaganju. Vseeno, v kontekstu politike trajnostnega razvoja je postavljena pot za njihovo obdelavo, za oceno teh sedimentov kot gradbenega materiala in še posebej kot novega veziva, ki ga je mogoče industrijsko izkoristiti in ki lahko izboljša fizikalne, kemijske in mehanske lastnosti betona. Ta študija je del raziskovalnega dela, opravljenega na oddelku za gradbeništvo Univerze v Mostaganemu (Alžirija), o vplivu izkopanega mulja iz jezu Fergoug na vedenje samozgoščevalnega betona (SCC) v svežem in v strjenem stanju, na mehanske lastnosti in na različne deformacije (krčenje). Namen je oceniti to blato v SCC in pokazati morebitne interakcije med sestavinami. Prikazani rezultati so dobra možnost za izdelavo SCC na osnovi kalciniranega blata.

Ključne besede: sediment, kalcinirano blato, samozgoščevalni beton, sveže stanje, trdo stanje, krčenje

\section{INTRODUCTION}

This work addresses general problems associated with durable development. The search for new building materials indicates that the research is focused on the possibilities of reusing industrial and natural waste as an alternative to the currently used materials that will become scarce in the near future.

River sediments in dams can be seen as an environmental and economic threat. The big quantities generated by the silting phenomena make the authorities perplexed about their depositions.

An assessment of these sediments made in the area of civil engineering proved that they could be used as building materials (bricks, aggregates and cementitious materials).

As these studies are in their first step, the reuse of sediments in concrete is poorly documented, particularly for self-compacting concrete.

It is known that SCC contains a very high amount of a paste that requires a large quantity of cement; so, its partial substitution with sediments can be a solution, reducing the use of cement.

\section{IDENTIFICATION OF FERGOUG DAM}

Regarded as one of the most silted dams in Algeria, the Dam of Fergoug (Figure 1) gave rise to the interest of several Algerian researchers who contributed various studies towards highlighting the causes, making it a disastrous dam.

These studies were primarily focused on explaining the phenomenon of silting, trying to find solutions for it and assessing the possibility of using the dredged sediments. ${ }^{1,2}$

During its existence, the dam underwent several operations of dredging; the first one was carried out in 1984 and 1986 when more than 10 million $\mathrm{m}^{3}$ of mud were removed. The second operation of dredging was carried out in 1992 when 6.5 million $\mathrm{m}^{3}$ of mud was evacuated. The last operation was launched in 2005, at a cost of 800 million DA, which is $130 \mathrm{DA} / \mathrm{m}^{3}$, and carried out by the National Agency for Dams. 


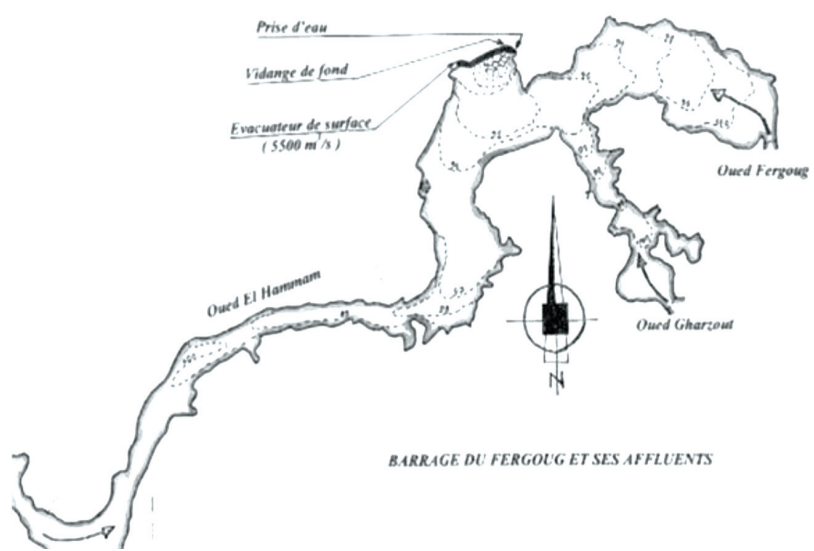

Figure 1: Fergoug Dam and its effluents Slika 1: Jez Fergoug s pritoki

In spite of these various attempts, the rate of the current silting is estimated to be $97.77 \%$ according to the bulletin published by the Agency for the Chergui Hydro Channel $[\mathrm{ABHC}]^{3}$.

\section{MATERIALS AND METHODS}

\subsection{Used materials}

\subsubsection{Cement}

The cement used was CEM I 42.5, made at the Zahana Factory (west of Algeria). The average physical and chemical characteristics of this cement are given in Table 1.

Table 1: Physical properties and chemical analysis of the cement Tabela 1: Fizikalne lastnosti in kemijska analiza cementa

\begin{tabular}{|c|c|}
\hline \multicolumn{2}{|c|}{ Physical properties of cement } \\
\hline Bulk density $\left(\mathrm{g} / \mathrm{cm}^{3}\right)$ & 1.18 \\
\hline Specific gravity $\left(\mathrm{g} / \mathrm{cm}^{3}\right)$ & 3.13 \\
\hline Fineness (Blaine) $\left(\mathrm{cm}^{2} / \mathrm{g}\right)$ & 3180 \\
\hline \multicolumn{2}{|c|}{ Chemical analysis of cement, $w / \%$} \\
\hline $\mathrm{SiO}_{2}$ & 20.90 \\
\hline $\mathrm{CaO}$ & 63.93 \\
\hline $\mathrm{MgO}$ & 1.45 \\
\hline $\mathrm{Fe}_{2} \mathrm{O}_{3}$ & 5.93 \\
\hline $\mathrm{Al}_{2} \mathrm{O}_{3}$ & 5.10 \\
\hline $\mathrm{SO}_{3}$ & 0.86 \\
\hline $\mathrm{Na}_{2} \mathrm{O}$ & 0.17 \\
\hline $\mathrm{K}_{2} \mathrm{O}$ & 1.34 \\
\hline Loss on ignition & 0.86 \\
\hline Carbonates & - \\
\hline $\mathrm{CO}_{2}$ & - \\
\hline $\mathrm{H}_{2} \mathrm{O}$ & 0.6 \\
\hline
\end{tabular}

\subsubsection{Mud}

The mud was taken downstream of the dam (Figure 2a) and activated thermally by burning it in a slow oven at a temperature of $(750 \pm 5){ }^{\circ} \mathrm{C}$ at a rate of $5{ }^{\circ} \mathrm{C} / \mathrm{min}$ for $5 \mathrm{~h}$, followed by steaming, crushing and sieving to $80 \mu \mathrm{m}$ (Figure 2b). The calcined mud (Figure 2c) was obtained and stored away from the air and any moisture. The
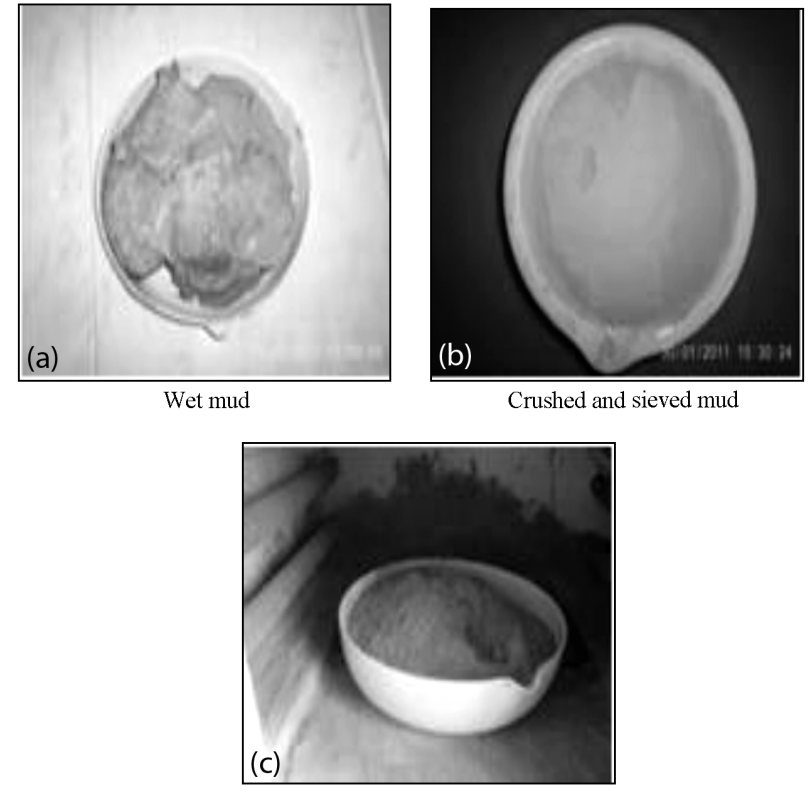

Calcined mud

Figure 2: Mud-preparation stages

Slika 2: Stopnje priprave blata

Table 2: Physical characteristics of the calcined mud

Tabela 2: Fizikalne značilnosti kalciniranega blata

\begin{tabular}{|l|c|}
\hline \multicolumn{1}{|c|}{ Test } & Values \\
\hline Bulk density $\left(\mathrm{g} / \mathrm{cm}^{3}\right)$ & 0.53 \\
\hline Specific gravity $\left(\mathrm{g} / \mathrm{cm}^{3}\right)$ & 2.62 \\
\hline Fineness (Blaine) $\left(\mathrm{cm}^{2} / \mathrm{g}\right)$ & 7964.00 \\
\hline
\end{tabular}

Table 3: Chemical composition of the calcined mud

Tabela 3: Kemijska sestava kalciniranega blata

\begin{tabular}{|l|c|}
\hline \multicolumn{1}{|c|}{ Component } & Content, $w / \%$ \\
\hline $\mathrm{SiO}_{2}$ & 54.69 \\
\hline $\mathrm{CaO}$ & 14.25 \\
\hline $\mathrm{MgO}$ & 3.08 \\
\hline $\mathrm{AL}_{2} \mathrm{O}_{3}$ & 15.49 \\
\hline $\mathrm{Fe}_{2} \mathrm{O}_{3}$ & 7.50 \\
\hline $\mathrm{SO}_{4}$ & - \\
\hline Loss on ignition & 1.87 \\
\hline
\end{tabular}

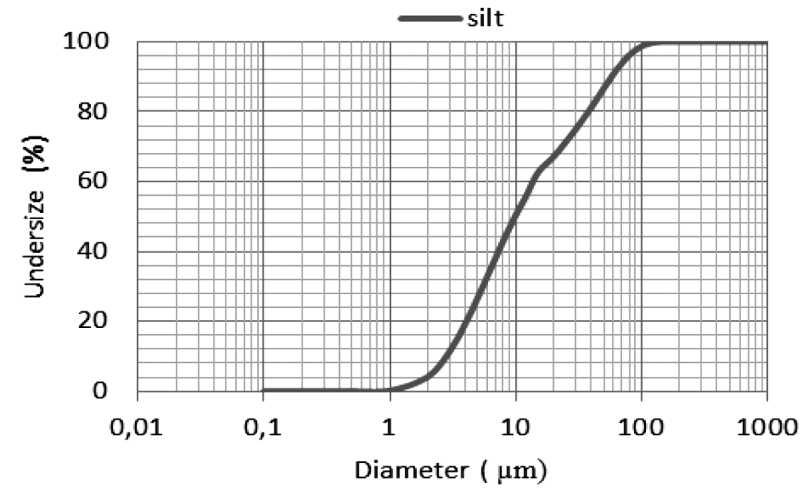

Figure 3: Fergoug-mud grain-size distribution (SIBELCO Laboratory, France, 2011)

Slika 3: Razporeditev velikosti zrn iz blata Fergoug (SIBELCO Laboratory, France, 2011) 
physical and chemical characteristics of the calcined mud are presented in Tables $\mathbf{2}$ and $\mathbf{3}$.

The grain-size analysis of the mud was carried out at the SIBELCO Laboratory (France). The results of the analysis of this mud are shown with a grading curve in Figure 3.

\subsubsection{Aggregates}

The aggregates used in this work consist of broken particles of limestone with a well graded distribution, obtained from the quarry of Kristel (the Oran area) and the sand from the siliceous sea, from the quarry of Sidi Lakhdar (the area of Mostaganem). Table 4 gives the characteristics of the aggregates for the whole of the concrete compositions.

Table 4: Physical characteristics of different aggregates

Tabela 4: Fizikalne značilnosti različnih agregatov

\begin{tabular}{|l|c|c|c|c|}
\hline & $\begin{array}{c}\text { Sea sand } \\
(\mathrm{Ss})\end{array}$ & $\begin{array}{c}\text { Quarry } \\
\text { sand (Sc) }\end{array}$ & \multicolumn{2}{|c|}{ Gravel (G) } \\
\hline Class & $0 / 2$ & $0 / 3$ & $3 / 8$ & $8 / 15$ \\
\hline Nature & Silicious & Limestone & Limestone & Limestone \\
\hline $\begin{array}{l}\text { Specific gravity } \\
\left(\mathrm{g} / \mathrm{cm}^{3}\right)\end{array}$ & 2.56 & 2.68 & 2.66 & 2.66 \\
\hline Absorption (\%) & - & - & 0.86 & 0.40 \\
\hline $\begin{array}{l}\text { Fineness } \\
\text { modulus }\end{array}$ & 1.64 & 2.63 & - & - \\
\hline $\begin{array}{l}\text { Sand equivalent } \\
\text { (ES) }\end{array}$ & 83.18 & 88.96 & & \\
\hline
\end{tabular}

\subsubsection{Admixture}

The admixture employed is a superplasticizer provided by the GRANITEX Society, a high water reducer, containing synthesized polymers combined according to the NF EN 934-2 standard. The MEDAFLOW113 allows obtaining concretes and mortars of a very high quality, maintaining the workability and avoiding the segregation. Its density is $1.12 \mathrm{~g} / \mathrm{cm}^{3}$ and its proportioning can vary from $0.8 \%$ to $2.5 \%$ of the binder mass.

\subsection{Concrete mixtures}

Four self-consolidating concretes were made to study the substitution effect of the cement with the calcined mud on the behavior in the fresh and hard states of the SCC. The concretes were made by adopting the method of the volume of the paste. The admixture proportioning is calculated in order to limit the segregation and bleeding and to obtain a distribution ranging between 60 $\mathrm{cm}$ and $75 \mathrm{~cm}$.

The aggregate proportioning $(G / S)$, the water/binder ratio $(W / B)$ and the volume of the paste were kept constant for all the compositions of the SCCs. Tests were carried out on the concretes containing various percentages of the substitution mud with respect to the volume of cement, i.e., $(10,15$ and 20$) \%$. The compositions of various mixtures are presented in Table 5.

Table 5: Mix proportions of concretes
Tabela 5: Razmerje mešanic v betonih

\begin{tabular}{|c|c|c|c|c|}
\hline \multirow{2}{*}{$\begin{array}{c}\text { Mix proportion } \\
\left(\mathrm{kg} / \mathrm{m}^{3}\right)\end{array}$} & \multicolumn{4}{|c|}{ Concrete mixes } \\
\cline { 2 - 5 } Cement & 450 & 420 & 408 & 395 \\
\hline Calcined mud & - & 35 & 52 & 66 \\
\hline Water & 225 & 218 & 216 & 213 \\
\hline Admixture & 5.7 & 7.5 & 8.3 & 9.8 \\
\hline$W / B$ & 0.5 & 0.5 & 0.5 & 0.5 \\
\hline Ss & 560 & 560 & 560 & 560 \\
\hline Sc & 251 & 251 & 251 & 251 \\
\hline Gravel $(3 / 8)$ & 333 & 333 & 333 & 333 \\
\hline Gravel $(8 / 15)$ & 499 & 499 & 499 & 499 \\
\hline
\end{tabular}

SCCR: $\quad$ Reference Concrete (0\% calcined mud)

SCCM10: Concrete with $10 \%$ of calcined mud

SCCM15: Concrete with $15 \%$ of calcined mud

SCCM20: Concrete with $20 \%$ of calcined mud

\subsubsection{Tests of the fresh concrete}

The characterization made in the fresh state of the concretes was limited to the tests recommended by $\mathrm{AFGC}^{4}$ including the slump flow, L-box, sieve stability and bleeding.

\subsubsection{Tests of the hardened concrete}

\subsubsection{Mechanical strength}

The mechanical compressive strength is an essential characteristic of a concrete material and a fundamental parameter of our study. Consequently, its evolution was measured for all the formulations of concrete studied within this work.

The samples used to determine the mechanical compressive strength of various studied concretes are cylindrical test tubes with a diameter of $11 \mathrm{~cm}$ and a height of $22 \mathrm{~cm}$. Once removed from the mold, they are preserved in water for a certain period $(1,7,28$ and 90$) \mathrm{d}$. To measure the average tensile strength, three samples $(7 \mathrm{~cm} \times$ $7 \mathrm{~cm} \times 28 \mathrm{~cm}$ ) were broken at various ages by means of three-point-bending tensile tests.

\subsubsection{Shrinkage deformation}

It is interesting here to observe the deformations of the hardened material (after $24 \mathrm{~h}$ ). For this purpose, two series of samples were produced and preserved in two different environments with and without a hydrous exchange with the external medium. The tests were performed to measure the total and endogenous shrinkage deformations. The shrinkage deformations were measured with a refractometer used on the prismatic test tubes with the size of $7 \mathrm{~cm} \times 7 \mathrm{~cm} \times 28 \mathrm{~cm}$, placed in an air-conditioned room with a relative humidity of (20 \pm 1$)$ ${ }^{\circ} \mathrm{C}$ or $(50 \pm 5) \%$, according to the following two conditions:

- A hydrous exchange of the material with the environment: the total shrinkage is obtained and it represents the sum of the endogenous and drying shrinkages.

- No hydrous exchange with the environment because the test tubes are covered with one or two sheets of 
self-adhesive aluminum paper: the endogenous shrinkage is identified.

The drying-shrinkage deformation is obtained from the difference between the total and endogenous shrinkage deformations.

Once removed from the mold, six test tubes relative to each concrete (three for the total shrinkage and three for the endogenous shrinkage) were tested over a very short period: first at its beginning, later the periodicity of the measurement increased with the time.

\section{RESULTS AND DISCUSSIONS}

\subsection{Index and the activity coefficient of the calcined mud}

The index of the activity noted, $I_{\mathrm{p}}$, is defined as the ratio between compressive strengths $f_{\mathrm{p}}(t)$ and $f_{0}(t)$ (Equation (1)) with respect to the strength of the standardized mortar containing $25 \%$ of the calcined mud as the cement substitution $\mathrm{p}$ and the reference-mortar strength (with cement only) (Table 6):

$$
I(p)=\frac{f_{\mathrm{p}}(t)}{f_{0}(t)}
$$

Table 6: Results of the compressive-crushing tests

Tabela 6: Rezultati tlačnih porušnih preizkusov

\begin{tabular}{|c|c|c|c|}
\hline Age & $f_{0}(t) / \mathrm{MPa}$ & $f_{\mathrm{p}}(t) / \mathrm{MPa}$ & $I(p)$ \\
\hline $28 \mathrm{~d}$ & 47.4 & 39.20 & 0.83 \\
\hline $90 \mathrm{~d}$ & 52.30 & 45.08 & 0.86 \\
\hline
\end{tabular}

\subsection{Fresh states}

The characterization results carried out on the concretes are presented in Table 7.

Table 7: Workability test results

Tabela 7: Rezultati preizkusov obdelavnosti

\begin{tabular}{|l|c|c|c|c|}
\hline \multicolumn{1}{|c|}{ Concrete } & SCCR & SCCM10 & SCCM15 & SCCM20 \\
\hline Slump flow $R / \mathrm{cm}$ & 66.5 & 65.4 & 63.6 & 63.3 \\
\hline$T_{50 \mathrm{~cm}} / \mathrm{s}$, slump flow & 3.5 & 3.3 & 3.1 & 3.2 \\
\hline$\left(H_{2} / H_{1}\right) / \%(\mathrm{~L}-\mathrm{Box})$ & 0.85 & 0.83 & 0.82 & 0.80 \\
\hline$T_{40} / \mathrm{s}(\mathrm{L}-\mathrm{Box})$ & 3.4 & 3.5 & 3.7 & 3.6 \\
\hline$\left(H_{2} / H_{1}\right) / \%(\mathrm{~L}-\mathrm{Box})$ & 8.47 & 7.55 & 6.90 & 4.55 \\
\hline Bleeding, \%o & 1.25 & 1.18 & 1.12 & 1.15 \\
\hline
\end{tabular}

\subsection{Workability (slump-flow test)}

It can be noted that all of the SCCs comply with the criterion of the flow spread where specified values lie between $63.3 \mathrm{~cm}$ and $66.5 \mathrm{~cm}$ (Figure 4), causing a lower viscosity. Although no limit is given for the times of the flow spread, the time needed to reach a $50 \mathrm{~cm}$ diameter $\left(T_{50}\right)$ is close to the values usually noted, i.e., $3 \mathrm{~s}$.

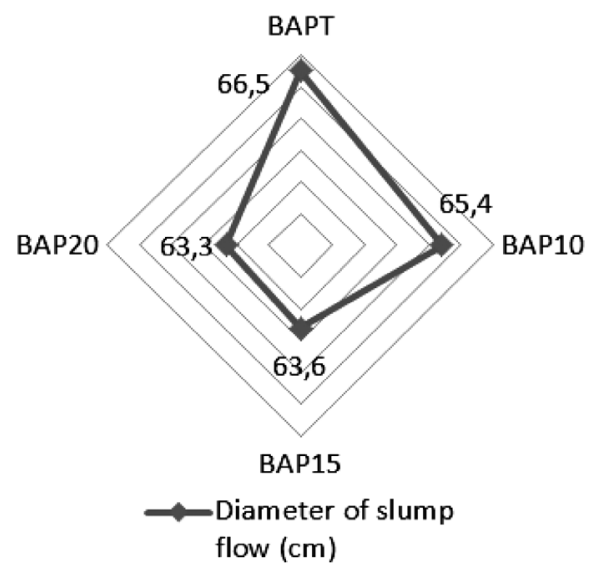

Figure 4: Diagram of the diameter of the slump flow Slika 4: Diagram premera pri preizkusu razleza

\subsection{Flowability (L-box test)}

The L-box test is used to assess the filling and passing ability of SCC. This is a widely used test suitable for a laboratory as well as site use. A concrete can be accepted if the fill ratio $\left(H_{2} / H_{1}\right)$ of the L-box is higher than $0.8^{4}$; the flowing times can be measured in order to assess the viscosity. The obtained results clearly show that the concrete present satisfies the ratio of $0.80-0.85$.

\subsection{Sieve-stability test}

For this test, the results in Table 7 show that all the SCCs have a segregation rate lower than $15 \%$, indicating a good stability. ${ }^{4}$ When determined as $0 \leq \Pi \leq 5 \%$, the resistance to the segregation is maintained to be "too significant" which is true in the case of SCCM20 where the paste is too viscous to run out through the sieve. ${ }^{5}$

\subsection{Bleeding test}

The results in Table 7 indicate that all the concretes meet the recommended value. The values obtained vary between $1.12 \%$ and $1.25 \%$.

\subsection{Hardened state}

\subsubsection{Evolution of the mechanical compressive strength}

According to the obtained results and curves represented in Figure 5, it is clear that the SCCR displays a good compressive performance at various testing stages compared to the concretes with the substitute material (SCCM). It is observed that over short periods the concretes have similar amplitudes; on the other hand, over long periods, their amplitudes start to move away from that of the SCC, except for the SCCM10, which displays a trend close enough to the SCCR observed between the 28th and 90th day.

The evolution of the compressive strength with respect to time shows that during a short-term period the 


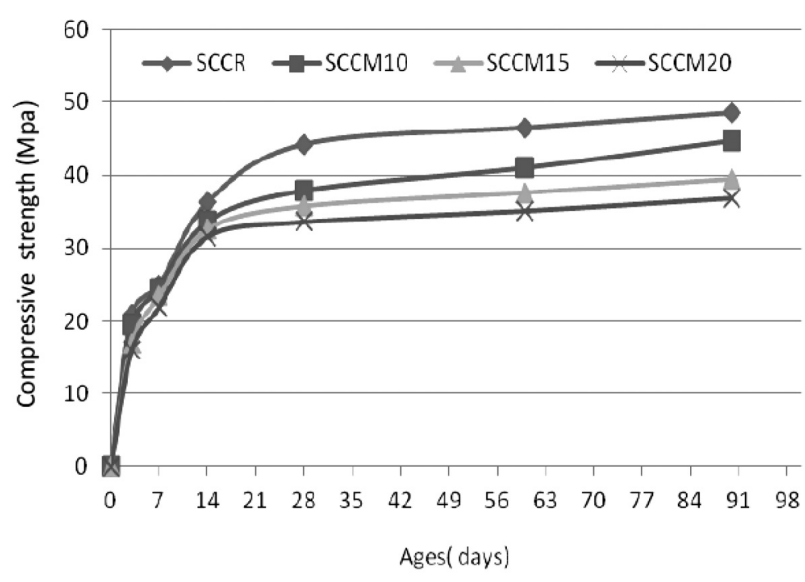

Figure 5: Compressive strength of concretes versus time Slika 5: Tlačna trdnost betona $\mathrm{v}$ odvisnosti od časa

evolution rate of the strength of the SCCMs is developing more slowly than that of the SSCR; nevertheless, it can be noted that the variation between the measured values is slightly different, especially for the SCCM10.

The measured values indicate that the SCCR reached $(48,60$ and 82$) \%$ of its compressive strength after $28 \mathrm{~d}$ for the testing ages of (3, 7 and 14) d, respectively. However, the SCCM10, SCCM15 and SCCM20 reached between $48-51 \%$ after $3 \mathrm{~d}, 64-65 \%$ after $7 \mathrm{~d}$ and $89-92 \%$ after $14 \mathrm{~d}$, which can only be explained with the densification effect. The calcined mud acted as the filler, filling in the pores and increasing the compactness of the cementitious matrix.

On the other hand, between the 28th and 90th day, it is the SCCM10 that evolves distinctly among the SCCMs. For these testing ages, the effect of the pozzolanic activity on the concretes can be distinguished. The evolution of this compressive strength can also be clearly noticed on the histogram presented in Figure 6, which also shows the effect of the variation of the $M / C$ ratio (the proportioning of the mud to cement) on the strength evolution.

However, it is interesting to note that even with the $20 \%$ substitution, the compressive strength remains

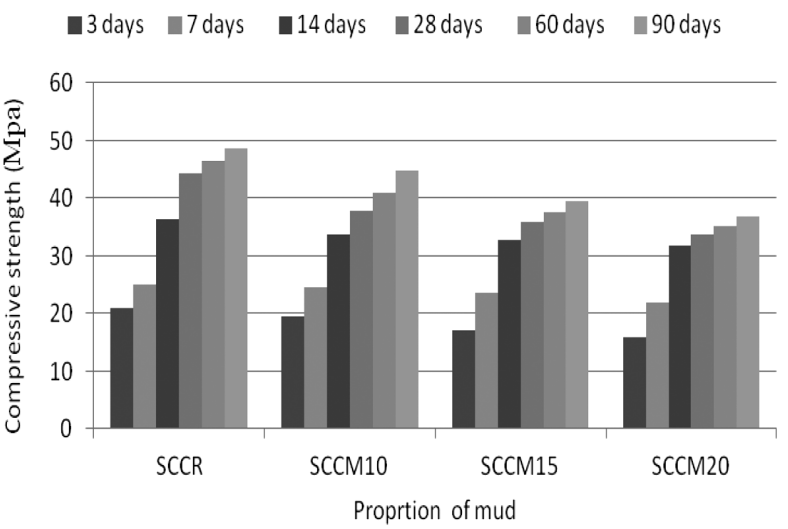

Figure 6: Histogram of evolution of the compressive strength with respect to the mud proportion

Slika 6: Histogram razvoja tlačne trdnosti glede na delež blata

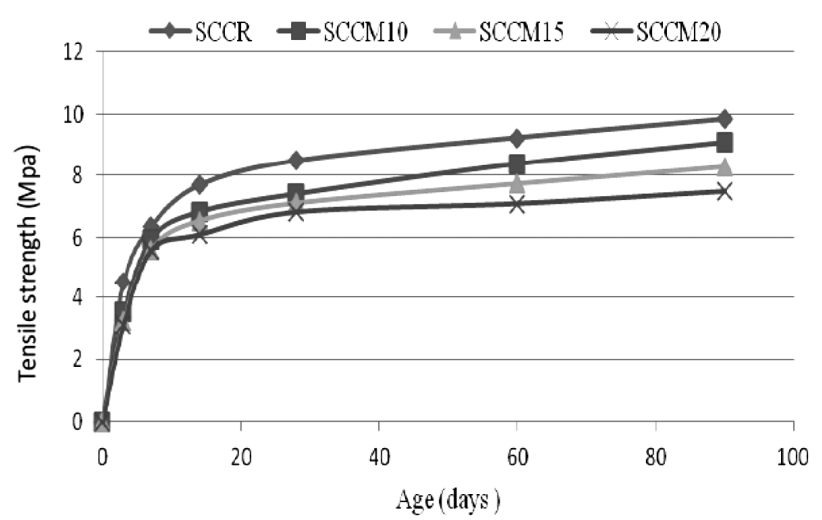

Figure 7: Evolution of the tensile strength at different ages Slika 7: Razvoj natezne trdnosti pri različni starosti

within the reasonable limit of $30 \mathrm{MPa}$ recommended by various construction specifications for building concretes.

\subsubsection{Evolution of the mechanical tensile strength}

It is known that the factors influencing the evolution of the compressive strength also influence the evolution of the tensile strength of concrete. The obtained results show that SCCMs developed a low tensile strength compared to the reference SCCR.

On Figure 7, we can see that the development of the tensile strengths follows the trend of the compressive strength and the evolutions of the strengths in the early period are identical, confirming the hypothesis that the mud acts as the filler.

It can also be noticed on Figure 7 that the tensile strength of the SCCM10 displays a convergence towards that of the SCCR as of the 28th day with respect to the two other concretes, indicating a sufficiently attenuated amplitude.

Figure 8 clearly shows that the reference concrete exhibits the best performances followed by the SCCM10. In general, the loss of the resistance to compression or traction does not exceed the mean value of $25 \%$ compared to the reference concretes irrespective of the age and the rate of substitution.

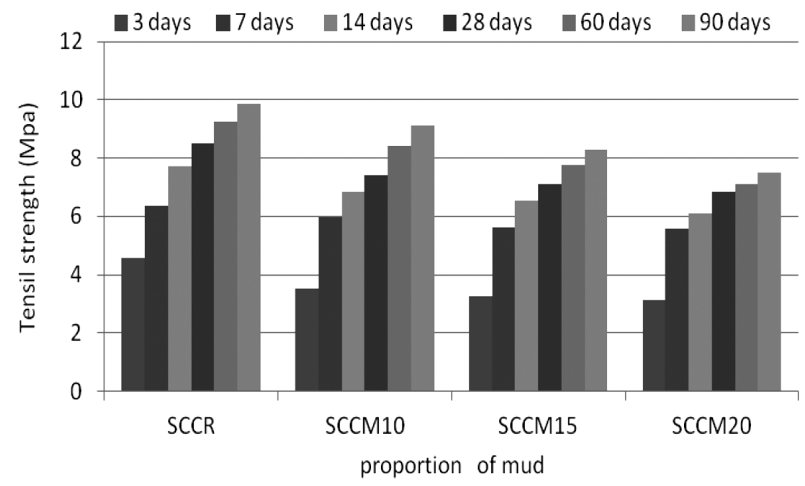

Figure 8: Histogram of the evolution of the tensile strengths with respect to the mud proportion

Slika 8: Histogram razvoja natezne trdnosti glede na delež blata 


\subsection{Different deformations}

It is known that the factor with the highest influence on the shrinkage is the quantity of the water used. For this reason and in order to better determine the problem, the $W / B$ ratio is kept equal to 0.5 . The compositions of the tested SCCs only differ in the proportion of the calcined mud substituting the cement, so all the differences in the behavior of the concretes are related only to this parameter.

\subsubsection{Endogenous shrinkage}

The endogenous deformations measured from the first day onwards are displayed on Figure 9. The types of the kinetics of the endogenous-shrinkage deformations of the concretes are rather similar; at the beginning they take similar and almost identical forms and start to differ with time.

Since this shrinkage is a consequence of the hydration phase $e^{6,7}$, it gives evidence of its kinetics and the quantity of formed hydrates. It can be observed that during the period from the 28th to 90th day, the orders of the magnitudes of the SCCMs approach that of the SCCR in comparison with the values displayed at the early age. At the 28th day, the SCCMs display reduced values, varying between $5.5 \%$ and $15.5 \%$ compared to the SCCR; on the other hand, between the 60 and 90th day, they are reduced by $4.6 \%$ to $12.45 \%$ compared to the SCCR, which shows that the deformations evolve in the same spindle, whereas the coming together of the values is a proof of the pozzolanic activity of the mud, which begins, a priori, after the 28th day.

The reduction in the endogenous shrinkage in the presence of the calcined mud can be explained with the fact that some hydrates (calcium aluminate) obtained via the pozzolanic reaction between the silica and the portlandite, are slightly expansive ${ }^{8}$, compensating for the dimensional variations due to the shrinkage. ${ }^{9}$ The shrinkages show the same development according to the mechanical compressive strength ${ }^{10}$, the auto-desiccation

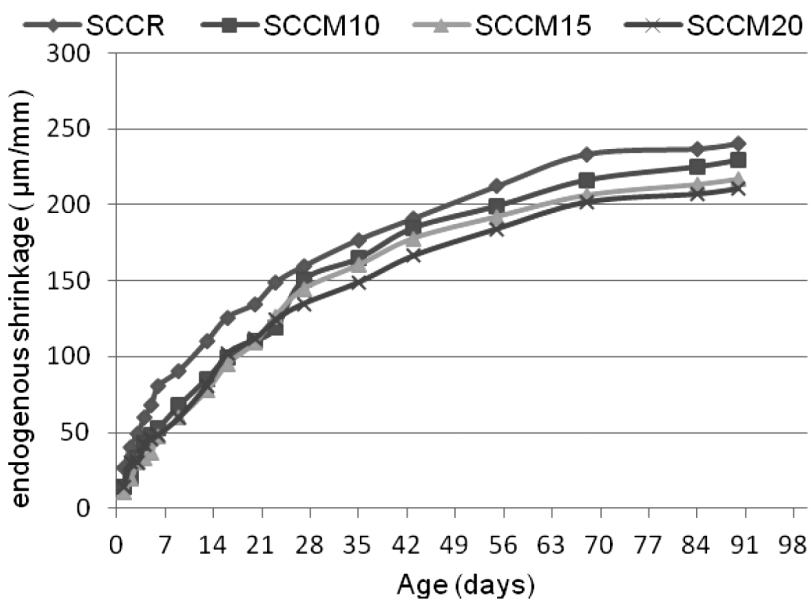

Figure 9: Evolution of the endogenous shrinkage versus time Slika 9: Razvoj notranjega krčenja v odvisnosti od časa known as the principal phenomenon, which governs the endogenous shrinkage growing under the influence of a high strength.

\subsubsection{Drying shrinkage}

This shrinkage develops from the surfaces exposed to the external environment; it is determined by calculating the difference between the total shrinkage and the endogenous shrinkage and it is presented with respect to time and mass loss. Figure 10 shows that the curves obtained for the SCC appear in a spindle, indicating that, due to drying, the component is not modified by the $M / C$ ratio. During the first phase, the values of the shrinkage of the SCCMs decrease compared to the SCCR, by the percentages varying between $21 \%$ and $52 \%$ on the 7 th and 28th day. On the other hand, during the second phase, the evolution starts to slow down until becoming almost constant up to the 90 day. Thus, it can be noted that the difference between the measured values decreases compared to the first phase, as it varies between $16 \%$ and $30 \%$, which proves that the amplitude of the shrinkage starts to stabilize.

Nevertheless, whatever the age, the SCCR always shows the highest values, contrary to the SCCMs as their values decrease with the increase in the rate of the calcined-mud substitution.

\subsubsection{Mass loss}

In order to try to improve the drying shrinkage, we also carried out follow-up tests of the test-tube mass shrinkage in order to quantify the hydrous exchanges.

The curves from Figure $\mathbf{1 1}$ show that the mass losses are in agreement with the evolution of the drying shrinkage; the values of the mass loss are very high and almost identical as of the first day for all the concretes; all the curves start with a linear part whose slope seems to decrease slightly with the time. In the intermediate zone, the curves are strongly nonlinear, which explains the reduction to low values due to the evaporation. After $60 \mathrm{~d}$, the mass losses start to decrease very slightly; they

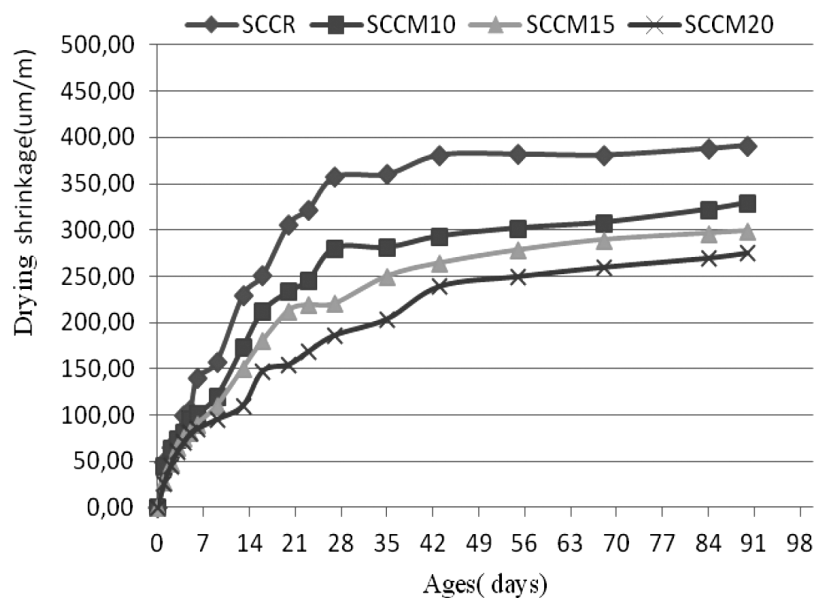

Figure 10: Evolution of the drying shrinkage versus time Slika 10: Razvoj krčenja zaradi sušenja v odvisnosti od časa 
N. E. BOUHAMOU et al.: INFLUENCE OF DREDGED SEDIMENT ON THE SHRINKAGE BEHAVIOR ...

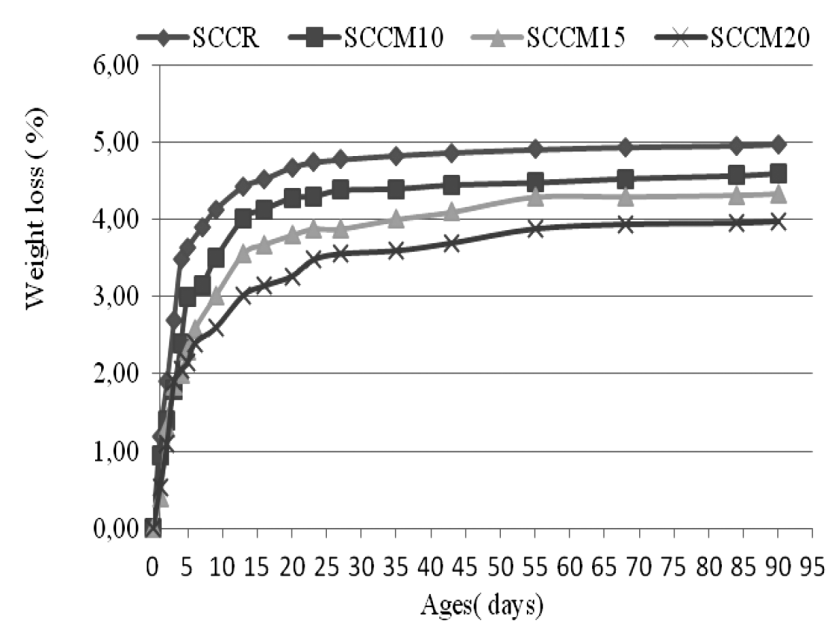

Figure 11: Evolution of the loss of mass versus time Slika 11: Razvoj izgube mase v odvisnosti od časa

are weaker for the concrete with the mud-cement combination than for the reference concrete. Finally, the effect of the $M / C$ ratio undoubtedly changes the hydrous-pressure development of the curves with respect to the degree of saturation. ${ }^{11}$

Figure 12 also shows that various drying-shrinkage evolution curves for the mass loss are presented in two phases; the first schematizes the first water departure without any consequence for the shrinkage, while the second one schematizes the evolution of the shrinkage with the water loss. The explanation is based the type of water and two families of pores: the water contained in the large pores leaves the material without causing a shrinkage, whereas the water contained in the small pores generates contractions of the material. ${ }^{12}$

\subsubsection{Total shrinkage}

It evolves very quickly for all the types of the test tubes kept in the air because of their sizes that make the desiccation more favorable. At the early stage, the shrinkage is almost independent of the composition of

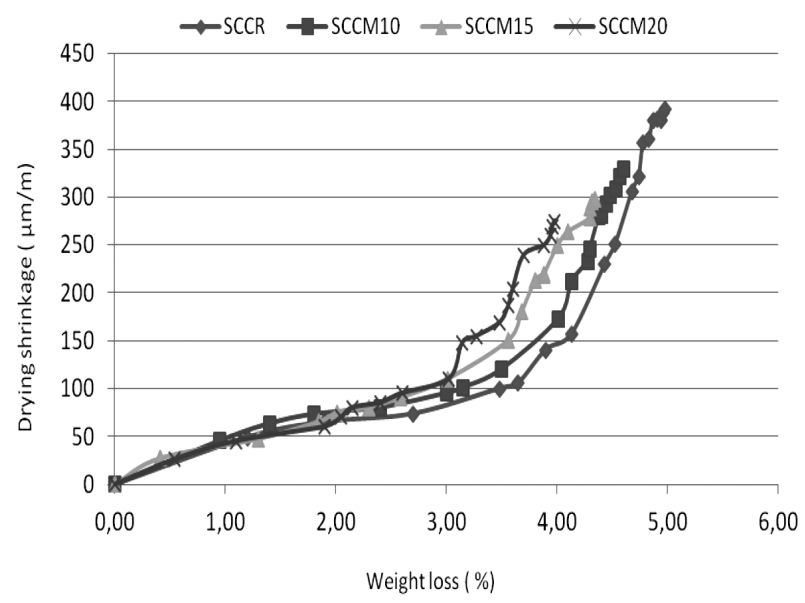

Figure 12: Drying shrinkage versus the loss of mass Slika 12: Krčenje pri sušenju v odvisnosti od izgube mase

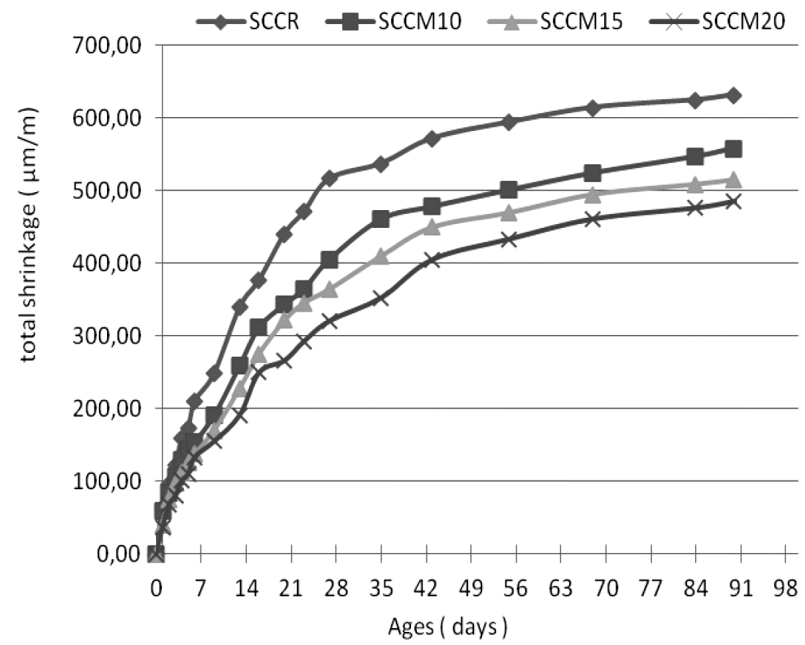

Figure 13: Evolution of the total shrinkage versus time Slika 13: Razvoj skupnega skrčka v odvisnosti od časa

the concrete. The values of the shrinkage are concentrated in the same spindle and the effect of the addition takes place only after the first week, with a slight superiority for the SCCR. After a long period, the presence of the mud decreases the final shrinkage with respect to the proportion of the substitute material.

Figure 13 shows a similar evolution of deformation for all the SCCs. This is the reason why at the very early stage we find it difficult to distinguish between the representative graphs for each concrete. The order of the magnitude on the 7 th day presents reductions, which vary from $14 \%$ to $36 \%$ for the SCCMs compared to the SCCR. After the 7th day, the shrinkage of the reference SCC evolves much more quickly and it is distinguished from the others up to the 90th day, having a similar amplitude.

It is also observed that for this shrinkage the reference SCC shows the highest values at all stages.

On Figure 14, the total shrinkage is plotted with respect to the $\lg (t)$ scale, rather than the drying shrinkage,

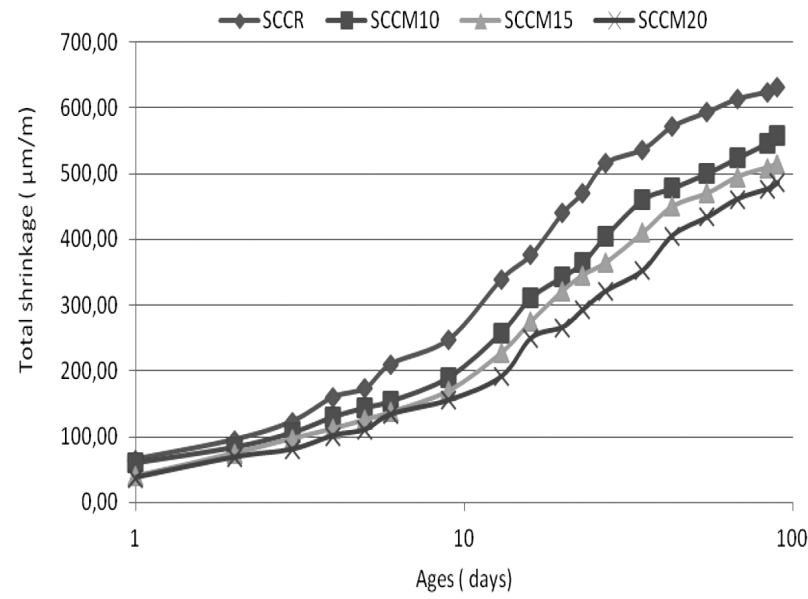

Figure 14: Total shrinkage according to the logarithmic scale Slika 14: Skupen skrček prikazan v logaritemski skali 
which is only a low estimate. Three phases appear; during the first one, the shrinkage gradually increases, during the second one, it evolves linearly with the logarithm of time and during the third one, the curve of the shrinkage inflects towards an asymptotic value.

\section{CONCLUSIONS}

Our study made it possible to confirm the possibility of using the mud from the Fergoug Dam as a partial substitute material for cement.

The principal conclusions obtained are as follows:

1. The study of the behavior of the SCC in the fresh state, with respect to the proportioning of the calcined mud, allows us to make the following observations:

- The results indicate that the SCCs containing calcined mud are more viscous and less workable compared to the reference concrete because, beyond the critical proportioning, the viscosity of the concrete increases with the increased amount of the substitute material.

- Only the SCCM20 presented too large a segregation according to the sieve test.

- In addition to the bleeding test, the values obtained with the tests of the simple flow, the L-box and the sieve stability decrease when the proportion of the calcined mud increases.

- A densification of the microstructure had a favorable effect by decreasing the bleeding, thus providing us with an idea on the improvement of the paste/aggregate interface.

2. In the hardened state, the mechanical tests of the compressive and tensile strengths carried out on the test tubes made of self-consolidating concrete with various amounts of the mud, in comparison with the reference concrete made of cement alone, gave the following results:

- The evolution of the strength is influenced by the $M / C$ ratio (the rate of the substitution of cement with the calcined mud); the results indicate that the compressive and tensile strengths decrease with the increase in the calcined-mud content; these values are very tolerable for the concretes employed for buildings constructions.

- The best values of the SCCM compressive and tensile strengths are obtained with the SCCM10, but the SCCR always exhibits the highest values. However, the use of a mineral addition involves the formation of a new $\mathrm{CSH}$, which fills in the pores of the hardened cement paste and densifies the structure of the paste, leading to a reduction in the porosity. These effects lead to an improvement of the mechanical strength.

3. With the tests of different deformations, carried out on the same concretes, we followed the evolution of free deformations in endogenous and drying condi- tions. The obtained results show that the calcined mud tends to slightly decrease the variety of deformations and it can be concluded that their kinetics is associated with the physicochemical mechanism, so:

- The endogenous shrinkage decreases with the increase in the proportioning of the substitute calcined mud.

- The compactness of the microstructure and the refinement of the pores lead to a fall in the permeability and prevent the diffusivity of water, consequently, decreasing the drying shrinkage and the mass loss.

- The total shrinkage follows the same principle, being influenced by the endogenous shrinkage more than by the drying shrinkage; it also decreases in accordance with the $M / C$ ratio, exhibiting a trend whereby the total shrinkage is an intrinsic phenomenon of the concrete.

- The analysis of the phenomenon of shrinkage in the presence of calcined mud indicates that this addition contributes to a decrease in the shrinkage amplitudes compared to the reference concrete. The $20 \%$ substitution seems to be the best option with respect to its contribution to the improvement of the microstructure and, finally, to the decrease in the shrinkage effects.

4. Finally, it is deduced that the calcined mud, due to its reactivity and fineness, influences the mechanical and other properties of the concretes:

- The pozzolanic reaction starts to be perceptible over a long period by improving the compressive and tensile strengths.

- The $10 \%$ substitution of cement is the optimum content to give the best mechanical performances, followed by the $15 \%$ and $20 \%$ substitutions.

- The $20 \%$ substitution is the optimum solution for a reduction in the shrinkage and mass loss due to an improvement in the microstructure, making the matrix more compact and minimizing the diffusivity, followed by the $15 \%$ and $10 \%$ substitutions.

- In conclusion, it can be deduced that the substitution of $15 \%$ of cement by the mud is the most interesting option that proves to be optimal since it is the average proportion that satisfies the two criteria: the strength improvement and the shrinkage reduction.

\section{REFERENCES}

${ }^{1}$ B. Remini, Qualification du transport solide dans le bassin versant de l'oued Isser, Application à l'envasement du barrage de Béni Amrane, $2^{\text {eme }}$ CMEE Alger, 2002

${ }^{2}$ A. Semcha, Valorisation des sédiments de dragage: Applications dans le BTP, cas du barrage de Fergoug, Doctoral Thesis, University of Reims, Champagne-Ardenne, France, 2006

${ }^{3}$ ABHC, Agence du bassin hydrographique Chott-Chergui de lžouest, 2007

${ }^{4}$ AFGC, Bétons Auto-Plaçants Recommandations provisoires, Association française de Génie Civil, 2008 
${ }^{5}$ F. Cussigh, M. Sonebi, G. Schutter, Project testing SCC-segregation test method, Proceedings of the Third international RILEM conference on self-compacting concrete, 2003, 311-322, http://www.rilem.org/gene/main.php?base=500218\&id_publication $=38$

${ }^{6}$ Andra, Référentiel géologique du site de Meuse/Haute-Marne sur le stockage géologique des déchets radioactifs à haute activité et à vie longue, Tome 2: matériaux cimentaires, 2005

${ }^{7}$ I. Yurtdas, Couplage comportement mécanique et dessiccation des matériaux à cimentaire: étude expérimentale sur mortiers, Doctoral Thesis, Université des sciences et technologie de Lille, 2003

${ }^{8}$ L. Courard, A. Darimont, M. Sschouterden, F. Ferauche, X. Willem, R. Degeimbre, Durability of mortars modified with metakaolin, Cement and Concrete Research, 33 (2003) 9, 1473-1479, doi:10.1016/S0008-8846(03)00090-5
${ }^{9}$ J. J. Brook, M. A. Megat Johar, Effect of metakaolin on creep and shrinkage of concrete, Cement and Concrete Research Composite, 23 (2001), 495-502, doi:10.1016/S0958-9465(00)00095-0

${ }^{10}$ B. Persson, Self-desiccation and its importance in concrete technology, Materials and Structures, 30 (1997) 5, 293-305, doi:10.1007/ BF02486354

${ }^{11}$ P. Turcry, Retrait et fissuration des bétons autoplaçants: influence de la formulation, Doctoral Thesis, Ecole Centrale de Nantes, France, 2004

${ }^{12}$ A. Neville, Properties of Concrete, 4th Edition, John Wiley and Sons, 1996 